\title{
PACLITAXEL/PLATINUM COMBINATION REGIMEN AND ALOPECIA
}

\author{
Nejat OZGUL ${ }^{1}$, Ozlem ERTEN ${ }^{1}$, Soner DUZGUNER ${ }^{1}$, Taner TURAN¹, Iskender KOG ${ }^{1}$, Nurettin BORAN ${ }^{1}$, \\ Ilknur BALTA ${ }^{2}$, Mehmet Faruk KOSE ${ }^{1}$
}

\author{
${ }^{1}$ Department of Gynecologic Oncology, Etlik Zubeyde Hanim Women Education and Research Hospital, Ankara, Turkey \\ 2 Department of Dermatology, Etlik Specialization Education and Research Hospital, Ankara, Turkey
}

\begin{abstract}
SUMMARY
Introduction: Alopecia in paclitaxel and platinum combination treatment that is widely used in gynecological oncology was evaluated.

Materials and method: The study evaluated retrospectively and the data of toxicity belonging to 470 patients who underwent surgery in the period from 1993 to 2006 because of epithelial ovarian cancer, fallopian tube cancer, primary peritoneal papillary serous tumor or advanced stage endometrial cancer and were given 6 cycles of paclitaxel and platinum chemotherapy as first line treatment and did not receive neo-adjuvant chemotherapy. The chemotherapy was started with $175 \mathrm{mg} / \mathrm{m}^{2}$ dose of paclitaxel. Then, carboplatin calculated from AUC=6 was infused in one hour or $75 \mathrm{mg} / \mathrm{m}^{2}$ dose of cisplatin was given with two-hour infusion. The treatment was administered with 21-day intervals. Toxicity was assessed according to the criteria established by the World Health Organization.

Results: Paclitaxel and cisplatin combination was given to 186 patients and paclitaxel and carboplatin combination was administered to 284 patients. Grade 4 alopecia was not observed. Alopecia did not develop in one patient. Grade 3 alopecia was found in 431 patients (91.7\%). Both chemotherapy combinations were similar in terms of the severity and frequency of alopecia $(p=0.722)$. Alopecia became remarkable as the cycles of chemotherapy advanced. Discussion: Alopecia with relation to paclitaxel and platinum chemotherapy combination observe in more than $90 \%$ of the patients at the end of the treatment. However, alopecia is reversible and improves after chemotherapy.
\end{abstract}

Key words: alopecia, paclitaxel, platinum

Journal of Turkish Society of Obstetrics and Gynecology, (J Turk Soc Obstet Gynecol), 2012; Vol: 9 Issue: Pages:

\section{PAKLITAKSEL/PLATIN KOMBINASYONU VE ALOPESI}

\section{ÖZET}

Giriş: Jinekolojik onkolojide sıklıkla kullanılan paklitaksel/platinum kombinasyonu sırasında gelişen alopesi değerlendirildi.

Gereç ve yöntemler: 1993-2006 tarihleri arasında epiteliyal over kanseri, tuba kanseri, primer peritoneal papiller seröz tümör veya ileri evre endometrium kanseri nedeniyle opere edilen ve first-line olarak altı kür paklitaksel/platinum kemoterapisi verilen, neoadjuvan kemoterapi almayan 470 hastaya ait toksisite verileri retrospektif olarak değerlendirildi. Kemoterapiye $175 \mathrm{mg} / \mathrm{m}^{2}$ dozunda paklitakselle başlandl. Takiben AUC=6'dan hesaplanan carboplatin 1 saatte infüzyonla veya sisplatin $75 \mathrm{mg} / \mathrm{m}^{2}$ dozunda 2 saatte infüzyonla verildi. Tedavi 21 gün arayla uygulandl. Toksisite Dünya Să̆llk Örgütü kriterlerine göre değerlendirildi.

Sonuçlar: Hastaların 186'sina Paklitksel/Sisplatin ve 284'üne Paklitksel/Carboplatin kombinasyonu uygulandi. Grade 4 alopesi izlenmedi. Sadece bir hastada alopesi gelişmedi. 431 hastada (\%91.7) Grade 3 alopesi belirlendi. Alopesinin

Address for Correspondence: Özlem Erten. Etlik Zübeyde Hanım Kadın Hastalıkları Eğitim ve Araştırma Hatanesi, Keçiören, 06010 Ankara Phone: + $90(505) 5856193$

e-mail: odle822002@yahoo.com

Received: 18 September 2011, revised:18 September 2011, accepted: 22 November 2011, online publication: 
şiddeti ve sıkliğl açısından her iki kemoterapi kombinasyonu benzerdi $(p=0.722)$. Kemoterapi kürleri ilerledikçe alopesi belirginleşmekteydi. Kemoterapi sonrası kalıcı alopesi gözlenmedi.

Tartşsma: Paklitaksel/platin kemoterapi kombinasyonuyla tedavi bitiminde hastaların \%90'indan fazlasinda alopesi gelişmektedir. Ancak alopesi geri dönüşümlü olup kemoterapi sonrast düzelmektedir.

Anahtar kelimeler: alopesi, paklitaksel, platinum

Türk Jinekoloji ve Obstetrik Derneği Dergisi, (J Turk Soc Obstet Gynecol), 2012; Cilt: 9 Sayl: Sayfa:

\section{INTRODUCTION}

The chemotherapeutic drugs act through cellular kinetics. Since the mitotic capacity of tumor cells is higher than normal cells, these cells are more susceptible to the cytotoxic drugs. However, the effects of chemotherapeutic agents are not specific to cells. Therefore, normal cells with high mitotic index (e.g. bone marrow and intestinal mucosa) are highly affected by cancer chemotherapy.

The side effects of chemotherapeutic agents may be cumulative and irreversible. This may result in changes in therapeutic doses, cessation of the treatment and even death. Hence, the toxicity does not allow to prolong disease-free survival time and to increase the quality of life of the patient, which are the goals of the treatment. Cumulative toxicity is rare with chemotherapeutic agents used in gynecologic oncology in usual doses and generally it is tolerable.

Paclitaxel is a chemotherapeutic agent that is widely used for gynecologic malignancies and acts through microtubules. It has been entered in gynecologic oncology practice as a consequence of the studies about evolving the treatment of ovarian cancer.

Currently, the combination of taxane (mostly paclitaxel) plus platinum (mostly carboplatin) is the standard treatment modality for the epithelial ovarian cancers and the preferred treatment procedure for advanced stage endometrial cancers.

The most common and major side effects of cytotoxic cancer therapy are bone marrow suppression, gastrointestinal system symptoms and alopecia. Alopecia becomes noticeable when at least $50 \%$ of hair is lost. More than $80 \%$ of the patients given antimicrotubule agents (paclitaxel etc.) may develop alopecia during chemotherapy ${ }^{(1)}$.

In this study, we aimed to determine alopecia caused by the combination of paclitaxel/platinum, which is used often as first-line therapy in gynecologic oncology.

\section{MATERIALS AND METHOD}

The toxicity data of 470 patients, who underwent surgery because of epithelial ovarian cancer, tubal cancer, primary peritoneal papillary serous tumor or advanced stage endometrial cancer and have taken six sessions of paclitaxel/platinum chemotherapy as firstline therapy, but not neo-adjuvant chemotherapy, in the period from 1993 to 2006 were evaluated retrospectively.

The attention was paid to the patients to have the performance status 2 or below according to the Gynecologic Oncology Group standards prior to the chemoterapy; that is bone marrow, hepatic and renal functions were adequate (leukocyte count $\geq 3.000 / \mathrm{ml}$; thrombocyte count $\geq 100.000 / \mathrm{ml}$; hemoglobin level $\geq 10 \mathrm{mg} / \mathrm{dl}$; total bilirubin, AST and ALT levels below twice the corresponding upper limit of normal; glomerular filtration rate $60 \mathrm{ml} / \mathrm{min}$ and over).

Chemotherapy was initiated with paclitaxel in a dose of $175 \mathrm{mg} / \mathrm{m}^{2}$. The calculated dose was given by 3 -hour infusion in $500 \mathrm{cc}$ of $0.09 \% \mathrm{NaCl}$ solution. Then, 1-hour infusion of carboplatin calculated by $\mathrm{AUC}=6$ in $1000 \mathrm{cc}$ of $5 \%$ dextrose solution or 2-hour infusion of cisplatin in a dose of $75 \mathrm{mg} / \mathrm{m}^{2}$ in $1000 \mathrm{cc}$ of $0.09 \% \mathrm{NaCl}$ solution together with $500 \mathrm{cc}$ of $20 \%$ mannitol was done. The drugs were given strictly in that order, because there are studies demonstrating that the patients tolerate well in that way ${ }^{(2)}$. The treatment was given with 21-day intervals. As premedication, dexamethasone infusion was done, which was initiated 60 minutes prior to chemotherapy and continued up to the time of chemotherapy. A 5 HT3 receptor antagonist was administered via 30-minute infusion starting one hour before the chemotherapy. Neither G-CSF nor erythropoietin was given prophylactically. The statutes of toxicity and eligibility to receive chemotherapy of the patients were checked with blood tests and biochemical analyses (leukocyte count, hemoglobin, thrombocyte count, urea, creatinine, 
AST, ALT and total bilirubin levels) performed once every ten days.

The toxicity was assessed by one researcher (IK) according to the criteria established by the World Health organization (Table I) ${ }^{(3)}$.

Table 1: According to WHO criteria, the degree of alopecia.

\begin{tabular}{ll}
\hline Alopecia & Finding \\
\hline Grade 0 & No hair loss \\
Grade 1 & Mild hair loss \\
Grade 2 & Modarate, patchy hair loss \\
Grade 3 & Full hair loss, reversible \\
Grade 4 & Full hair loss, irreversible \\
\hline
\end{tabular}

The statistical analyses were done using Chi-square test on SPSS (Statistical Package for Social Sciences) ver. 17. software running under Windows XP operating system. The $p$ value $<0.05$ was set to be significant.

\section{RESULTS}

The median age was 55 years (18 to 63) in the group of the patients. Of the patients, 186 patients were given the combination of paclitaxel/cisplatin and 284 patients were administered paclitaxel/carboplatin combination. The primarily involved organs were ovaries (403 patients), endometrium (38 patients), ovaries and endometrium (13 patients), uterine tubes (seven patients), primary peritoneal serous papillary carcinoma (seven patients) and cervix (two patients).

Grade 4 alopecia was not observed. Only one patient $(0.2 \%)$ did not have alopecia, while 469 patients (99.8\%) had different stages of alopecia. Grade 3 alopecia was identified in 431 patients $(91.7 \%)$. No difference was found between two chemotherapy combinations in terms of severity and incidence of alopecia (Table II).

Table II: The relationship between chemotherapy and other toxicities.

\begin{tabular}{llll}
\hline Alopecia & \multicolumn{3}{c}{ Per Head } \\
& $\begin{array}{l}\text { Paclitaxel/ } \\
\text { Cisplatin }\end{array}$ & $\begin{array}{l}\text { Paclitaxel/ } \\
\text { Carboplatin }\end{array}$ & p \\
Grade 0 & - & $1(\% 0.3)$ & 0.722 \\
Grade 1 & $1(\% 0.5)$ & $3(\% 1.1)$ & \\
Grade 2 & $12(\% 6.5)$ & $22(\% 7.7)$ & \\
Grade 3 & $173(\% 94)$ & $258(\% 90.2)$ & \\
Grade 4 & - & - & \\
\hline
\end{tabular}

As the sessions progress, alopecia developed more often (Table III). After the first session, 61 patients (13\%) did not have alopecia, while 46 patients (9.8\%) developed grade 3 alopecia. Grade 3 alopecia was found in $49.6 \%$ of the patients after 2 nd session, in $73.4 \%$ of the patients after 3 rd session, in $85.3 \%$ of the patients after $4^{\text {th }}$ session, in $91.1 \%$ after 5 th session and in $91.7 \%$ of the patients after 6 th session. The progression of alopecia by chemotherapy sessions was similar in both chemotherapy combinations (Table IV).

Table III: Evaluation of alopecia progresses during courses of chemotherapy.

\begin{tabular}{llllllllll}
\hline $\begin{array}{l}\text { Course of } \\
\text { chemotherapy }\end{array}$ & \multicolumn{1}{c}{ Grade 0 } & \multicolumn{9}{c}{ Grade 1 } & \multicolumn{2}{c}{ Grade 2 } & \multicolumn{2}{c}{ Grade 3 } \\
& n & \% & n & \% & n & \% & n & \% \\
\hline 1. course & 61 & 13 & 184 & 39.1 & 179 & 38.1 & 46 & 9.8 \\
2. course & 6 & 1.3 & 57 & 12.1 & 174 & 37.0 & 233 & 49.6 \\
3. course & 1 & 0.2 & 16 & 3.4 & 108 & 23 & 345 & 73.4 \\
4. course & 1 & 0.2 & 5 & 1.1 & 63 & 13.4 & 401 & 85.3 \\
5. course & 1 & 0.2 & 5 & 1.1 & 36 & 7.7 & 428 & 91.1 \\
6. course & 1 & 0.2 & 4 & 0.9 & 34 & 7.2 & 431 & 91.7 \\
\hline
\end{tabular}

Table IV: development of grade 3 alopecia progresses, according to protocol.

\begin{tabular}{lllllll}
\hline $\begin{array}{l}\text { Chemotherapy } \\
\text { protocol }\end{array}$ & \multicolumn{4}{c}{ Grade 3 Alopecia (\%) } \\
& $\begin{array}{l}\text { 1.course } \\
\text { 2. course }\end{array}$ & 3. course & 4. course & 5. course 6. course \\
\hline $\begin{array}{l}\text { Paclitaxel/ } \\
\text { Cisplatin }\end{array}$ & 11.8 & 49.2 & 73.8 & 86.6 & 91.4 & 94 \\
$\begin{array}{l}\text { Paclitaxel/ } \\
\text { Carboplatin }\end{array}$ & 8.5 & 49.8 & 73.1 & 84.5 & 90 & 90.2 \\
\hline
\end{tabular}

\section{DISCUSSION}

Chemotherapeutic agents can be used individually or multiple in combination. Combined medical treatment has been developed on the basis of tumor biology. The main goal is to kill more cancer cells and to prevent from or delay the emergence of resistance against the drugs. For this reason, the drugs used in combination must have different mechanisms of act, must not be antagonist to each other, and the cells must develop resistance via different mechanisms against each drug. With combined medical treatment, anticancer efficacy increases, however, toxicity profile becomes wider. The toxicity is designated by the action mechanism, dose and type of administration of the drug, pharmacokinetics 
and pharmacodynamics of the drug, administration of protocol of the drug or drugs (combination), individual's capacity of hepatic, renal and bone marrow functions. Furthermore, individual's age, general status (extensiveness of the disease, nutritional status, performance), metabolic pleomorphism and tolerance affects toxicity(4).

Hematologic toxicity is significant with paclitaxel. Severe neutropenia is seen in $35-75 \%$ of the patients ${ }^{(5)}$. Usually, anemia and thrombocytopenia is mild. Peripheral neuropathy is another toxicity caused by paclitaxel, which is important and impairs life quality of the patient ${ }^{(6)}$. The development of alopecia is undoubted with the doses over $130 \mathrm{mg} / \mathrm{m}^{2}$.

With the use of cisplatin, the most common side effects involve neurotoxicity, nephrotoxicity, moderate-degree bone marrow suppression, allergic reactions and severe nausea and vomiting. Nephrotoxicity is dose-dependent and develops in case the serum level of the drug exceeds $6 \mu \mathrm{g} / \mathrm{ml}^{(5)}$

Carboplatin-mediated bone marrow suppression is the main toxicity seen during the use of this drug; this toxicity is dose-dependent and mostly reversible. Anemia develops in $60-70 \%$ of the patients and grade 4 neutropenia occurs in $15-20 \%$ of the patients $(5)$

Many anti-cancer drug classes may cause alopecia, however, alopecia occurs more often with four major drug groups. Alopecia develops in more than $80 \%$ of the patients with anti-microtubule agents (paclitaxel, etc.), in more than $60 \%$ of the patients using alkylating agents (cyclophosphamide, etc.), in $60-100 \%$ of the patients given topoisomerase inhibitors (doxorubicin, etc.) and in $10-50 \%$ of the patients administered antimetabolites (5FU, leucovorin, etc.) ${ }^{(1)}$. It was found that combined treatments were more frequently associated with alopecia in comparison with single agent treatments $(1,7)$.

In this study, grade 4 alopecia was not observed, however, similar to the literature data, grade 3 alopecia was found in $91.7 \%$ of the patients. As the chemotherapy sessions advanced, alopecia became more prominent. The agent causing alopecia in the chemotherapy protocols was paclitaxel, so that the severity and incidence of this side effect was similar with both chemotherapy combinations.

The development of alopecia is related to the growth cycle of the hair follicle. The growth cycle has basically three phases called anagen, catagen and telogen. Anagen is the phase in which regeneration of hair root, follicular growth and production of hair body occur most intensively. Catagen is the degenerative phase, in which total regression of follicles and apoptosis in some parts occur. In telogen phase, the follicle is stable ${ }^{(7)}$. Chemotherapy-induced alopecia occurs when the hair follicles are in anagen phase. Ninety to ninety-five percent of hairs remain in anagen phase for approximately 2 to 6 years. In contrast, $1 \%$ of hairs remains in catagen phase for 2-3 weeks, and less than $10 \%$ of hairs remain in telogen phase for 3-4 months (8).

Alopecia affects patient's physical appearance, selfconfidence, sexuality, and patient's fight against cancer in a negative way. In a study with women, it was found that $47 \%$ of them perceived alopecia to be the most traumatic side effect, and $8 \%$ of women rejected chemotherapy because of alopecia $(9,10)$.

Chemotherapy-induced alopecia is usually reversible and approximately 3 to 6 months after treatment, hairs begin to grow again. The re-growing hairs may have changes in hair pattern, grayish in color, and reduced density $(1,11)$.

Many treatment protocols have been attempted to prevent chemotherapy-induced alopecia; these involve drug-specific antibodies, certain agents modifying growth cycle (cyclosporine A, minoxidil, AS101), antioxidants (NAC), cytokine and growth factors (EGF, FGF, interleukin 1), apoptosis inhibitors (M50054) and skull skin cooling method ${ }^{(7,12)}$. Although some of these protocols shorten the period of chemotherapyinduced alopecia, they are not able to prevent from alopecia because many different chemotherapeutic agent are used together ${ }^{(7)}$.

In conclusion, the patients should be informed about alopecia that occurs often due to chemotherapeutic agents used for gynecologic malignancies and they should be assured that this toxicity is most likely transient. So that, patient's compliance to the treatment increases and the chemotherapy can be given throughout the required number of the sessions.

\section{REFERENCES}

1. A. M.Hussein. Chemotherapy-induced alopecia: new development. South. Med. J. 1993; 86: 489- 96.

2. du Bois A, Luck HJ, Bauknecht T, Mobus V, Bochtler H, Diergarten K, et al. Phase I/II study of the combination of 
carboplatin and paclitaxel as first-line chemotherapy in patients with advanced epithelial ovarian cancer. Ann Oncol. 1997; 8(4): 355- 61.

3. WHO handbook for reporting results of cancer treatment WHO Offset Publication 1979, No: 148.

4. Bookman M. Principles of chemotherapy in gynecologic cancer. In: Principles and Practice of Gynecologic Oncology. Hoskins WJ, Perez CA, Young RC, Barakat RR, Markman M, Randal ME (eds). 4th edition 2005, Philadelphia, p: 46187.

5. Verschragaegen C, Horpwitz S. Cytotoxic drugs in gynecologic oncology. In Cytotoxic Drug Therapy In Gynaecological Oncology: Principles And Practice, Chapter 18, Péter Bõsze, (Ed). CME J Gynecol Oncol 2002; 6 (1): 319- 43.

6. Rowinsky EK, Cazenave LA, Donehower RC. Taxol; a nove investigational antimicrotubule agent. J Natl Cancer Inst 1990,
82 (15): $1247-59$

7. Wang J, Lu Z, Au JLS. Protection Against Chemotherapyinduced Alopecia. Pharmaceutical Research 2006; 23(11): 2505- 14 .

8. S.M. Jankovic and S. V. Jankovic. The control of hair growth. Dermatol. Online J. 1998; 4: 2

9. McGarvey EL, Baum LD, Pinkerton RC, et al: Psychological sequelae and alopecia among women with cancer. Cancer Pract 2001; 9: 283-9.

10. Mundstedt K, Manthey N, Sachsse S, et al: Changes in selfconcept and body image during alopecia induced cancer chemotherapy. Support Care Cancer 1997; 5: 139- 43.

11. V. J. Dorr. A practioner's guide to cancer-related alopecia. Semin. Oncol. 1998; 25: 562- 70.

12. Grevelman EG, Breed WPM: Prevention of chemotherapyinduced hair loss by scalp cooling. Ann Oncol 2005; 16: 352- 8 . 